\title{
"Techno-R" Technology in Teaching the Students of Linguistic Direction the Latin Language
}

\author{
${ }^{* 1}$ Elena K. Kuzmina, ${ }^{2}$ Valentina N. Vassilieva, ${ }^{3}$ Alsu F. Valeeva, ${ }^{4}$ Elena R. Porshneva \\ 1, 2, 3,4 Kazan Federal University, Leo Tolstoy Institute of Philology and Intercultural Communication, \\ ${ }^{4}$ N.A. Dobrolyubov Nizhny Novgorod State Linguistic University \\ E-mail: lenysinka@yandex.ru<mailto: lenysinka@yandex.ru>,contact: 89503226949
}

\section{Received: 21st October 2017 Accepted: 16th November 2017, Published: 31st December 2017}

\begin{abstract}
In this article the content of pilot study on the Techno R technology developed at the Kazan Federal University is stated. Authors showed specifics of use of the given technology in teaching Latin to form the language competence. Latin lost communicative function of a living language, but kept the cultural and educational value. Studying the Latin is necessary at assimilation of modern Romance languages. It should be noted that both the phonetic and grammatical phenomena of modern Romance languages can be acquired students only on the basis of studying the Latin. In article the authors studied the scientific base of technology presented by the theory of an interiorization intellectual P. Y. Galperin's actions, the theory of transfer and methods informatively - practical activities in the field of training in foreign languages. The principles of remedial Techno $\mathrm{R}$ technology, its thematic and operational structures are shown in article. Authors developed experimental material for check of efficiency of remedial Techno $R$ technology in formation of language competence on Latin material. Experimentally obtained data were subjected to statistical processing by a method of mathematical statistics "Student's T-criterion". The received value of T-criterion> 2 says about efficiency of Techno $R$ technology in teaching Latin.
\end{abstract}

Keywords: Technology, Experiment, Latin, Knowledge, Skills, Quality of Training.

\section{Introduction}

Latin as an integral part of fundamental higher education is a factor of formation of the language personality in the conditions of the globalization processes happening in a modern language picture of the world. One of the theoretical purposes of teaching
Latin in Liberal Arts College is development at pupils of the relation to lingua Latina as to language of historical resources, philosophical treatises, its perception as language foremother, a uniform source of Romance languages which 720 million inhabitants of the globe speak. The culturological and historical background of development of language, division of Romance languages into subgroups proceeding from linguistic and cultural and historical reasons, are visually presented in N. Ostler's work as "Ad Infinitum" [1]. Latin is necessary when studying modern Romance languages as history of these languages, many phonetic and grammatical phenomena, and features of lexicon can be understood only on the basis of knowledge of Latin. It relates also to the German languages (English, German) because Latin exerted a great influence on their grammatical and lexical system. Studying the classic language promotes increase in linguistic education of future expert in the field of language, creates prerequisites for expansion of the training opportunities of the linguistic disciplines involving students in various cogitative and speech activity. In the course of formation of linguistic base and speech skills acquaintance to Latin allows to track emergence and development of the Romance languages learned by students in higher education institution.

Knowledge of Latin helps to realize language as system, to master Indo-European language categories, to be guided in all-linguistic problems. As the classic written language of Indo-European system, Latin is a key to understanding of the modern languages, helps to comprehend their similarity and distinctive features. It is a basis of the European education - in Latin within two millennia the people of Europe created the culture. During Studying the Latin there is an increase in level 
of all-linguistic competences, horizons and scientific erudition of students are broadened. Language basis facilitates studying the living foreign languages in lexical and grammatical plans. Systematically there is an increasing knowledge of the native language, the base of vocational training of students is put, and their common cultural level develops. The developing value has studying the grammatical categories and syntactic designs which are available or absent in other languages. The logical thinking of trainees is under construction on the basis of the understanding of inflectional character of Latin and free words order in the sentence demanding conscientiousness and scrupulousness of the translation of texts.

Poll of the students learning Latin revealed linguistic difficulties which they experience when studying this language. Meaning that at department of Romance philology of Institute of philology and cross-cultural communication of Leo Tolstoy of the Kazan federal university the remedial technology under the name "Techno R" is developed (the abbreviation of "techno" designates technology, "P" designates result), we, being on the way of search of an effective technique of teaching Latin, decided to apply this technology in educational process, through experimental check. Authors of this technology [2,3] consider that it considerably increases quality of education. Justification of this opinion is stated [4] earlier. Pilot studies were conducted both at comprehensive school, and in higher education institution on the example of training in French [2]. Authors believe that this technology is applicable to training in any language. Let's give basic provisions of Techno R technology. Its scientific base is the theory of transfer, the theory of intellectual actions of P. Y. Galperin and the theory of methods of informative practical activities of the Kazan didactic school [3]. Basic principles of technology following:

- Principle of shipping of knowledge, skills, abilities, ways of intellectual actions;

- Principle of generality of educational tasks;

- Principle of stage-by-stage formation of language and speech competences.

The Techno R technology consists of eight thematic blocks (lexicon, grammar, phonetics, spelling, audition, 2179 speaking, reading and the letter [2]. The first four blocks are intended for formation of language competence, the second four blocks reflect types of speech activity and are directed to formation of speech competence.

In the operational plan structure of technology following:

- Statement of an educational task (teacher);

- Studying an approximate basis of a linguistic phenomenon (joint activity of the teacher and trainee);

- A training in performance of a task (independently or under the leadership of the teacher);

- Control actions for identification of level of the acquired training material;

- Determination of level of the formed competence, both the teacher, and the student.

As Latin has general education value, is an independent subject matter, before us its side of the general education subject forming language competence reveals. According to mission of Latin in educational space our research fits into the block of formation of language competence of Techno R technology.

\section{Materials and Methods}

The system analysis of mistakes of trainees allows us to establish their alleged causes and to plan a way of elimination of problems in formation of language competence. Reasons of mistakes, in our opinion, following: trainees do not see a community of the educational tasks set for them, they doubt the choice of the correct option, having appeared in a situation of the choice of the grammatical phenomenon or a lexical unit, often do not understand the nature of own mistakes. Meaning that educational process has bilateral character - the teacher pupil, it is also necessary to analyze work of the teacher and to reveal weak points. As a result of the analysis of the techniques used in teaching Latin we revealed that a weak point is the approximate basis of speech actions.

The main method of a research was the experiment on the basis of Techno $\mathrm{R}$ technology. We created experimental group which corresponds to population of the students learning Latin. The course of an experiment was the following. Experimenters made a 
cut of knowledge of students which found the following results. Quantity of mistakes on grammar of Latin from 9 to 20 of 26 control positions are recorded.

Further on Techno R technology the task was set: to learn to determine unmistakably type of conjugation of a verb or inducement of a noun by identification signs in comparison. For realization of an objective the approximate basis of language actions - the stage demanding obligatory mutual activity of the teacher and trainees was fulfilled. The attention of students was concentrated on morphological similarity of Latin as language basis, and the learned foreign language: grammatical meanings (time, the person, number at a verb, case at a noun) are expressed within one word form; on syntactic typological similarity, the coinciding and differing phenomena. The general characteristic of a Latin verb (Verbum) was presented in parameters: categories of a verb, structure of a grammatical meaning of a verbal form, basis and main forms of a verb, classification signs. The short generalized material according to the grammatical characteristic of a verb presented in the form of summary tables as evident material allowed students to pass to performance of the positions of an experiment concerning definition like conjugation, the person and number of a verb and the procedure of the conjugation limited to a framework of Praesens Indicativi Activi. A number of positions of an experiment mentioned a noun (nomen Substantivum) and also one-declined and a heteroclitic combination of a noun and an adjective where the grammatical category of noun gender has crucial importance. Theoretical generalization concentrated attention of students that Latin has the same classes of names that the Russian, and learned foreign language. Grammatical categories of names and a form of their expression were marked out; the genitive case is accurately acquired (Genetivus Sing.) as a formal, identification sign like inducement of a noun, final elements of all types of inducement which knowledge allows the trainee to decline correctly set part of speech, noting similarity and distinctions in the mastered foreign language. Three last positions of an experiment concerned grammatical analysis and translation of sentences in Latin with definition such categories as a case and number of a noun, the person and number of a verb.

2180
On starting positions of an approximate basis of language actions the training in performance of an objective was organized, namely: conjugation of verbs of four types, inducement of nouns 1-5 like inducement, inducement of the phrase "nounadjective", recognition of parts of speech with determination of their grammatical categories and translation of sentences.

\section{Result}

After training in Techno $\mathrm{R}$ technology in students the examination was offered that was a cut of knowledge and skills of Latin. Results of a cut following: students made from 7 to 10 mistakes from 26 control positions. For definition of reliability of experimentally obtained data we used a method of mathematical statistics "Student's T-criterion" [5]. Transfer of quality indicators of cuts to quantitative allowed us to calculate value of statistical result on "Student's T-criterion". We received value $\mathrm{t}>3,7$. It is known that if $\mathrm{t}$-criterion $>2$, then the calculated value admits significant. Thus mathematical assessment of experimentally obtained data showed a validity of results.

Further we will try to show how the Techno $\mathrm{R}$ technology corresponds to the known technologies of training in foreign languages.

\section{Discussion}

In training in foreign languages various technologies forming communicative competence which part both language and speech competences are used. For example, the modular technology is in a stage of development [6] now, the Web Quest technology [7, 8, 9] gains ground. As training material substantial aspects of information technologies are used, game technologies, modular training, and also pedagogical systems of formation of the polylingual personality are widely known [10]. Each technology has the mission and structure. The Techno R technology developed by us has no contradictions with other technologies. It represents, figuratively speaking the "fast linguistic help" based on humane approach to the identity of the trainee, developing his informative forces - thinking, memory, imagination. A number of the experiments made by us on the example of training in French 
showed reliable results with an accuracy from $95 \%$ to $99 \%$. On the basis of the trial and training experiment on Latin we can draw conclusions on efficiency of Techno $\mathrm{R}$ technology in training of language competence.

\section{Conclusion}

1. On the basis of the conducted pilot study efficiency of Techno $\mathrm{R}$ technology in teaching Latin as to a general education subject of a humanitarian cycle, namely, in formation of language competence in antique languages is established.

2. The Techno R technology is based on generalization of educational tasks that allows students to carry out transfer on new educational tasks on the basis of the fact that the mechanism of transfer of knowledge, skills and abilities generalization is.

3. The Techno $\mathrm{R}$ technology developed at the Kazan federal university is not in a conflict with other known technologies as its mission consists in correction of knowledge, skills and abilities in acquisition of foreign languages. It is successfully combined with communicative, information, game, modular, design and other technologies. Its application is effective not only in training in living foreign languages, but also classic languages.

\section{Acknowledgement}

The research is performed according to the Russian Government Program of Competitive Growth of Kazan Federal University.

\section{References}

[1] N. Ostler. Ad Infinitum: A Biography of Latin. Bloomsburry Publishing; 2009, p. 400.

[2] Vasilyeva V. N. Remedial Techno R technology in training in the French language. Modern French and innovative technologies of its teaching: Materials of the International scientific seminar (on March 23-24, 2017). Kazan: Heter, 2017; p. 170.

[3] Vasilyeva V. N. Psychology and didactic basis of remedial technology of training in French. Urgent problems of Romance languages and modern techniques of their teaching: Materials of the International scientific and practical conference (on October 27-28, 2016). Kazan: Fatherland; 2016, pp. 139-149.
[4] Antonova N.V., Vassilieva V.N., Kononenko M.V. The problems of quality of education in foreign language teaching/Journal of Language and Literature. ISSN: 2078 - 0303, vol.7, No 2. May, 2016, pp.159162.

[5] Grabar M. I., Krasnyanskaya K. A. Application of mathematical statistics in pedagogical researches. Nonparametric methods. M.: Pedagogika; 1977, p. 136. [6] Dominique Markey, Elena Porshneva. L'enseignment modulaire en langues etrangeres. Urgent problems of Romance languages and modern techniques of their teaching. Materials III of the International scientific and practical conference. Kazan: Heter; 2015, pp. 157-169.

[7] Dodge B. Some thoughts about Web Quests - 19951997. - URL: http://webquest.Sdsu.edu/about webquests.html

〈http://webquest.Sdsu.edu/about\%20webquests.html> (date of the address 03.03.2017).

[8] Lamb A. Locate and Evaluate Web Quests. 20002004. Edu Scapes. Teacher Tap. Internet resourses. Web quests. - http://eduscapes.com/tap/topic4.htm (date of the address 03.03. 2017)

[9] March T. Working the Web for Education. Theory and Practice on Integrating the Web for Learning. 1997-2001.

<http://www.ozline.com/learning/theory.html> (date of the address 03.03. 2017)

[10] Nizamieva, L.R., Nazarova, G.I., Ostroumova, O.F. Teaching French as a Foreign Language in the Multilingual Environment (The Example of Tatarstan Republic). The Social Sciences; 2016, 11(6), pp. 10351041. URL: <http://medwelljournals.com/abstract/? doi=sscience. 2016.1035.1041> (date of the address 03.03.2017). 